\title{
THE USE OF VIDEO BROADCAST IN TEACHING LISTENING-SPEAKING
}

\author{
Tri Wahyuni Floriasti dan Suciati \\ Universitas Negeri Yogyakarta \\ email:triwahyunifloriasti@uny.ac.id
}

\begin{abstract}
(Title: The Use of Video Broadcast in Teaching Listening-Speaking). The latest technology, which comes like storm, gives us extra help in revealing the unseen that is beyond our reach and touch the untouchable in our hands. The technology gives us potential to do things we haven't been able to do before. One of the greatest challenges to the classrooms of today is mobile technology. As teachers, it's our job to make sure that students who are considered as digital natives learn through the omnipresence of the mainstream media. The world around us is changing in terms of communication and interaction that affect the way people see, think and learn the present environment, and connect with others. In education, we have three options when dealing with these changes: avoid it, struggle with it, or embrace it. It is our duty to prepare and adjust the classroom of today ready for tomorrow. Thus, this writing attempts to review the new trend in technology, the use of video broadcasting in teaching listening-speaking.
\end{abstract}

Keywords: listening-speaking, video broadcasting, media

\section{INTRODUCTION}

Digital technology is changing from interactive Internet to social networking sites to smart phones with built-in cameras. The world around us is changing in terms of information and communication technology (ICT) that affect the way people see, think and learn the present environment, and connect with others. Traditionally, people share their life face to face in limited social life environment, but now in the $21^{\text {st }}$ digital technology era, for example daily interaction and professional communication is mediated by technology, for example: email; social media such as Facebook or Twitter; 'video' games and online/mobile messaging and telephony (Walker, 2014).

The way in which the ICT change has affected and reshaped the social, cultural, educational, economic and political landscape of human life. In the same time, it also give affect for the growing numbers of non-native speakers of English who try to speak English internationally in order to marketize themselves in tough competitive global market especially in ASIA. Thus, English as an International language (EIL) McKay (2002) and ICT are considered as a "must" tools to survive.

Next, in this literature review, I try to write three points briefly: (a) English as an
International Language (EIL); (b) the use of ICT in Language education; (c) sociocultural and economic background to use ICT in learning EIL.

English as International Language (EIL) means "International English is used by native speakers of English and bilingual users of English for cross- cultural communication (McKay, 2002). EIL is frequently defined as English as a Lingua Franca (ELF), English as a Global Language (EGL) (Jenkins, 2006; Phan Le Ha, 2005). The development of Information and Communication Technology, which comes like storm, gives it extra help in spreading English around the world, which is spoken by the increasing number of nonnative English speakers. The number of people speaking English as a second language is roughly estimated 450 million, and the total of 750 million represents speakers of English as a foreign language. In short, three out of four English users are now non-native speakers (Crystal, 2004).

Moreover, the spread of EIL and the ICT development have resulted in the need for learners to possess new $21^{\text {st }}$ century knowledge and skills (Warschauer, 2000a in Jung, 2006). The report of enGauge 21st Century Skills for 21st Century Learners 
(2003) proposed four skill clusters, digitalage literacy, inventive thinking, effective communication, and high productivity. Thus, it gives teachers opportunities to transform their ways of teaching and learning English as a lingua franca in the $21^{\text {st }}$ century (Block \& Cameron, 2002; Burns \& Coffin, 2001; Warschauer, 2000a). For example, as teachers, it's their job to make sure that students who are considered as digital natives learn through the omnipresence of the mainstream media. One of the greatest challenges to the classrooms of today is digital learning. Technology offers learners opportunities for much more valuable communicative interaction in the target language than was ever possible in the traditional language classes (Jung, 2006).

\section{THE EFFECTIVE USE OF DIGITAL TECHNOLOGIES}

The effective use of digital technologies requires them to be used within a pedagogic approach that fits the learners, the domain and the context (Walker, 2015). The effectiveness should be found in the way of, for example, teachers set course goals act as an important first step toward the successful use of technology in classrooms. The next vital aspect is integration. It can be done after understand the structure of ICT (walker, 2015), syllabus, and English material. When teaching learning process involves the new technologies, teachers and learners need to be aware of barriers such as learners' characteristics, and economic and sociocultural background, such as, religious value that forbid female learners to have interaction virtually. It is because, for instance, in certain part of Indonesia, female and male attend different Islamic school, they do not have interaction, so it will against their values. Teachers need to set the integration of Language education and ICT very carefully.

Learning is also a social process that has transformed the medium of face-to- face to e-learning. In teaching learning process, the growing trend of digital culture put the learner in control of the instructional process. E-learning can be found on the internet is a hi-tech way, which is widely used in teaching learning process. Yogyakarta State University provides students with e-learning, which is known as Be- smart, in order to meet the upper standard of transferring knowledge and facilitating students to open the global world. It can be the train for UNY to get what people of say World Class University. Thus, integration of technology in education and as a part of their lives is a culturalphenomenon.

The integration can be done through Be-smart. It gave extra space for me and for my students in letting the material went deeper in their mind, then hopefully, it changed their learning culture. E-learning is commonly referred to the intentional use of networked information and communications technology in teaching and learning (Naidu, 2006: 1). It seems like e-learning offer tremendous opportunities for communicating, displaying, and sharing information in teaching learning process.

Recently, more and more schools have computer rooms and connected to the Net for teaching purposes (Dudeney, 2007: 32). Two questions come up then, can e-learning influence teaching and learning? If the answer is positive, then how is e-learning useful to class participants?

First year student teachers of English Education Department get a packed of subject that they need to master. I teach Listening and Speaking for freshmen. There are two kinds of meetings that they have in these classes: classroom meeting and be- smart. There will be 16 meetings in one semester that they need to attend for both listening and reading.

\section{Listening-Speaking class}

Listening is a compulsory subject and one of receptive skills that is not easy to be mastered by the student teachers (Nation, 2009). According to the English Education curriculum (2009: 29) listening subject provides students with basic skills in comprehending simple oral discourses through recorded voice of native speakers. Materials are presented in a variety of short functional texts with exercises on pre- listening warm-up activities, listening for specific information/literal comprehension, listening for gist/reorganization, making inferences, listening and making evaluation, 
and appreciation. Students' classroom activities include individual work, pair work, and group work. Evaluation on students' achievement is based on classroom participation, home assignments, the mid and the finaltest.

According to English Education curriculum (2009: 32-33) the other receptive skill, reading, describes as follows while developing the basic competencies of reading initiated at secondary schools (such as getting general and specific information from the text, getting the main ideas and detailed information from the text, deducing the meaning of words, phrases and sentences based on the context, and explaining relations between parts of the text through grammatical cohesive devices), with a mastery of vocabulary within 4500 words and relevant grammatical structures, the course also aims at the development of the skills of inferencing, analyzing, synthesizing, and speed reading. In order to aid the language development, both simplified and authentic texts of general topics may be used. Text types may include Spoof, Recount, Report, Description, Narration, News item, Procedure, and Explanation. While individual performances are noted, pair and group work shouldbeencouraged. Assessment of success is based on portfolios and mid-term as well as final examinations.

Receptive skill, listening, plays as input for student teachers. Meanwhile, speaking and writing, the productive ones, play as output. Normally, students acquires input first, then they can produce spoken or written expression. The logic is the more student teachers get input the better performances they produce. In order to be able to demonstrate comprehensible meaning, students need to get relevant and meaningful input either from listening or reading so that they acquire not only full understanding of the messages being spoken but also the model to communicate them in the appropriate speaking context. The more students get input from listening, the richer the knowledge they acquire then the more fluent they become. One investigation from Dupuy (1999) in Nation (2009) about "narrow listening" - an approach based on Krashen's idea, reported improvements in students listening comprehension, fluency, and vocabulary as well as increased confidence in French. The improvements were resulted from listening as many times as they wish to a range of $1-2$ minute aural texts on a range of familiar and interesting topics.

Student teachers need to get more input not only from the printed book but also from other media such as audio-visual material that can be utilized to scaffold their knowledge so that students have good model how to speak naturally and read comprehensively. Be-smart gives extra help to teacher in meeting the need of soft media, such as audio material, video, text with pictures. In addition, be-smart provides student teachers with sources, forum, link to other useful and supportive sites, chat, quiz, and offlineactivities.

The major aims of using be-smart are to support student teachers in learning and comprehending the content and getting opportunities to practice reading, listening and writing simultaneously. Integrating technology into classroom instruction requires a careful selection of instructional material and thoughtful preparation so that student teachers get the intended content and eager to come back for more (Wong and Chee 2003: 17) cites Williams (2003). Thus, preparation is an important phasebefore integrating technology in the classroom instruction so that teacher and student teachers can get advantages from the useful digital media in be-smart, besides the printed material, textbook and other classroom media, which are presented in the class.

\section{VIDEO BROADCAST IN BE-SMART}

Due to the lack of using other media but English book or printed materials, student teachers did not get more chance to develop what they got. They needed to get more input not only from the printed book but also from other media such as Video Broadcast that can be played to scaffold their knowledge so that students had good model how to speak naturally. A set of video broadcast material was uploaded in the sites so that student could download them easily. Thus, they got big opportunities to practice and increase their listening ability as it can be found in picture 1 . 


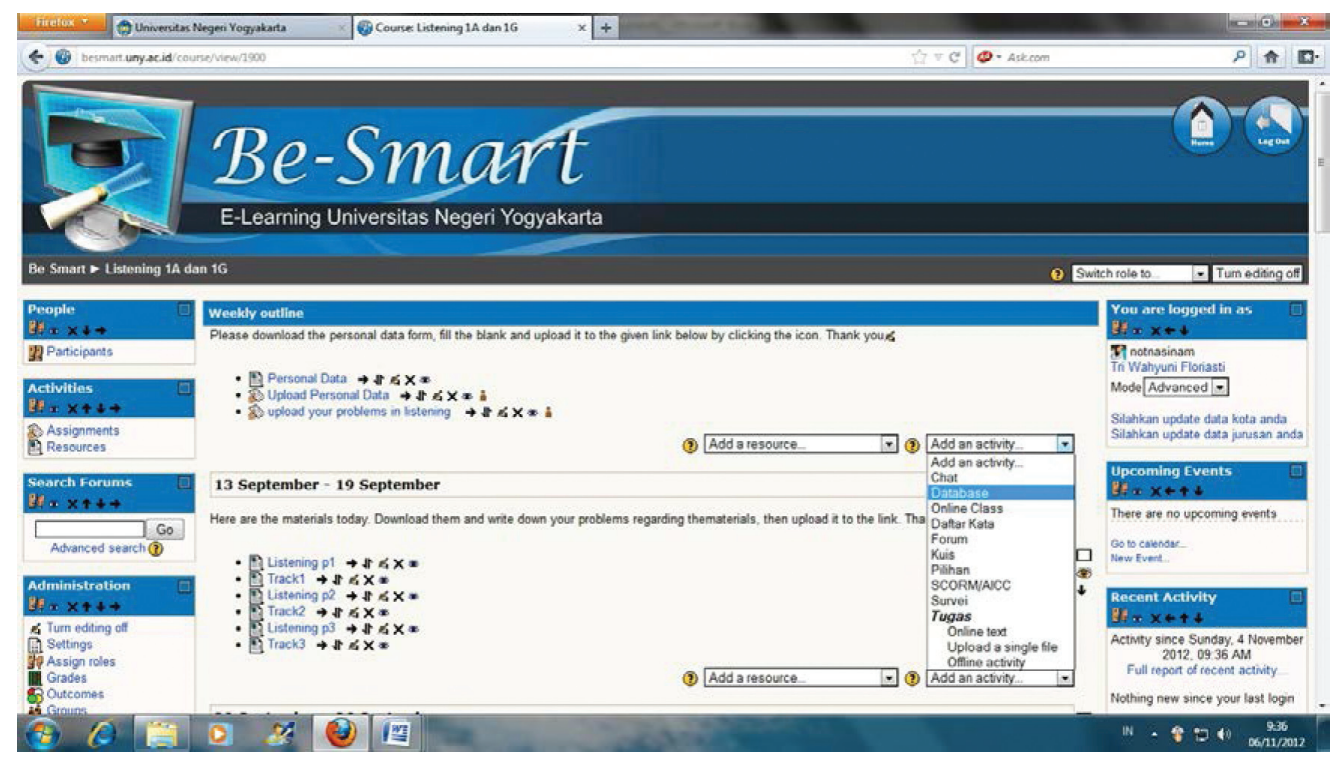

Picture 1. Listening audio material

The power of Information Technology has tremendous impacted in human life. "You are what you use" can be employed to describe the "gadget" situation. People put their life in the Internet. Today, we find that Internet is about us. Life is more practical, for example people use a gadget to manage three or four businesses in one time and anywhere. This potential advantage is a challenge for teachers who need to put English closer to students in their daily life (Floriasti, 2012). It can be used as a media in teaching listening skills. Once students downloaded digital material fromthebe-smart and installed it to their hand phones, they started learning the material anytime and anywhere. It means that they have the control how and when to learn the material. It can be matched with their learning style and habit.

In contrast, this advantage cannot be found in pictures, which are displayed in the limited time allocation in the class. When the class is over, so does the media (Floriasti, 2012). Students have the control how and when to study the digital material. Therefore, the students are getting closer to listening skills. The more they listen to the material, the more they acquire vocabularies, and the more they can produce sentences fluently.

Based on the explanation above, it can be stated that student teachers need more independent activities, which provide more practice in listening which contain good model of accuracy, fluency, pronunciation, rhythm, intonation, grammar and standard rate of delivery so that students have standard Speaking skills. Thus, students need audiovisual media that gives them extra help in acquiring spoken micro skills and improving their listening abilities as well.

In the future, their abilities will be a potential factor that can be used as good model in listening and reading skills for their students and excellent material designer. Basically student teachers are designed to be junior or senior high school teachers that meet the competencies. Their capability in teaching and designing material meets with characteristics of good language teachers are (Allen, 1980 in Brown, 2001:429)

Technical Knowledge: (1) understands the linguistic systems of English phonology, grammar, and discourse, (2) comprehensively grasps basic principles of language learning and teaching, (3) has fluent competence in speaking, writing, listening to, and reading English, (4) knows through experience what it is like to learn a foreign language, (5) understands the close connection between language andculture, and (6) keeps up with the field through regular reading and conference/workshop attendance 
Pedagogical Skills: (1) has a wellthought-out, informed approach to language teaching, (2) understands and uses a wide variety of techniques, (3) efficiently designs and executes lesson plans, (4) monitor lessons as they unfold and makes effective mid-lesson alterations, (5) effectively perceives students' linguistic needs, (6) gives optimal feedback to students, (7) stimulates interaction, cooperation, and teamwork in the classroom, (8) uses appropriate principles of classroom management, (9) uses effective, clear presentation skills, (9) creatively adapts textbook material and other audio, visual, and mechanical aids, (10) innovatively creates brand-new materials when needed, and (11) uses interactive, intrinsically motivating techniques to create effective tests and lessons.

It is expected that what student teachers get in their study can give them some inspiration and motivation how to design material, use appropriate approaches and give suitable media in teaching learning process. Therefore, it can be used as a pattern to develop English material in the future for different purposes and emphases, and assess students' performance. In addition, the audio-visual media will give them an alternative way to give input for their future students in enriching listening skills.

Moreover, student teachers need to know how to assess their future students. They might follow the way I did in reading class. I used portfolio in assessing student teachers' achievements as displayed in picture 5 above. Portfolio is very useful in assessing students' achievements either in reading or listening class. According to Devalenzuela (2002) a student portfolio is a systematic collection of student work and related material that depicts a student's activities, accomplishment, and achievements in one or more subject.

\section{CONCLUSION}

I expect that the result of using besmart as supporting media will provide students with adequate knowledge in mastering reading and listening and giving student teachers with individual opportunities to practice and improve listening skills. Furthermore, as a result of acquiring good model from listening student teachers have confident to speak and not worried about making mistake and error, then give them good model how to speak naturally in daily context and formal situation as well. In the future, their abilities will be potential factors that can be used in the upper level of study, and in their class. It can be said that using be-smart influences the way student study and the time they spent aswell.

Moreover, it is a good opportunity for me to prepare and design innovative activities through the use of be-smart. It is a useful practice in integrating technology into classroom instruction, as it should support the classroom interaction and the student teachers needs in improving listening and gaining more skills in reading.

\section{REFERENCES}

Anderson, M., \& Anderson, K. (1998). Text Types in English 2. 1. ed. South Yarra: MacMillan Education Australia PTY LTD.

Brown, H.D. (2001). Teaching by Principles. $2^{\text {nd }}$ ed. Englewood Cliffs, N.J.: PrenticeHall.

Burns, A., \& Coffin, C.(Eds.). (2001). Analyzing English in a global Context: A Reader. London and New York: Routledge.

Block, D., \& Cameron, D. (Eds.). (2002). Globalization and Language Teaching. London and New York: Routledge.

Cresswell, J. W. (2003). Research Design: Qualitative, Quantitative, and Mixed Methods Approaches. Thousand Oaks, CA:Sage.

Crystal, D. (2004). The Language Revolution. Cambridge: Polity Press.

Chee, Tan Seng., Wong, Angela F.L. (2003). Teaching and Learning With Technology.Singapore: Prentice Hall Pearson.

Cruickshank, D., Jenkins, D., Metcalf, K. (2006). The Act of Teaching. New York: The McGraw-Hill Companies, Inc.

De valenzuela, Julia Scherba de. (2002). Defining portfolio assessment. http:// 
www.unm.edu/ devalenz/handouts/ portfolio.html. Nov 8,2012

Dudeney, G. (2007). The Internet and the Language Classroom. Cambridge: Cambridge Universitypress

English Education Curriculum. (2009). Yogyakarta: Universitas Negeri Yogyakarta Press.

English Learners in $21^{\text {st }}$ Century Classroom. www.pearsonhigered.com

Floriasti, T. W. (2012). It's MobileEra: Teaching Speaking Skills Using Podcast and Movie to the Teacher Students of Yogyakarta State University. Conference proceeding accepted and presented in $10^{\text {th }}$ ASIA TEFL New Delhi, India. October 4-6, 2012

Floriasti, T.W. (2012). Developing Character Building Through Multicultural Reading Text. Proceeding Presented at International Seminar ACLL Osaka, Japan, April 28,2012

Halverson, R., Smith, A. (2009). How New technologies (and have not) Changed Teaching and Learning in Schools Journal of Computing. Journal Teacher Education. Volume 26/Number 2 Winter 2009-10.. www.iste.org

Heick, Terry, Promoting a culture of learning, feb 14, 2014, http://www.edutopia.org/ blog/promoting-a-culture-of-learningterry-heick

Jenkins, J. (2006). Current perspectives on teaching World Englishes and English as a Lingua Franca. TESOL Quarterly, 40(1), 157-181.
Johnson, B., \& Turner, L. A. (2003). Data collection strategies in mixed methods research. In A. Tashakkori \& C. Teddlie (Eds.). Handbook of mixed methods in social and behavioral research (pp. 167-187). Thousand Oaks, CA: Sage.

Jung, She-Hwa. (2006). The use of ICT in Learning English as an International Language. Dissertation. University of Maryland.

McKay, S. L. (2002), Teaching English as an International Language. Oxford: Oxford University Press.

Naidu, Som. (2006). E-Learning A Guide Book of Principles, Procedures and Practices. New Delhi: CEMCA

Nation, I.S.P. \& Newton, J. (2009). Teaching ESL/EFL Listening and Speaking. New York: Routledge.

Phan Le Ha (2005). Toward a Critical Notion of Appropriation of English as an International Language. Asian EFL Journal, 7(3),30-42.

Thao, V.T. (2003). The Contribution of Multimedia Tools to EFL Setting Unfamiliar with Technology. Asian EFL Journal, 5(3), 1-14.

Warschauer, M. (2000a). The Changing Global Economy and the Future of English Teaching,TESOL Quarterly, 34 (3), 511-535.

Walker, A. (2014). The Danger of "Digital Natives" Myth. Retrieved from aishawalker.com July 30, 2016.

Walker, A. (2015). Language Skills in Digital Age. Retrievedfromaishawalker.com July 30, 2016. 